\title{
JC virus antibody index in natalizumab-treated patients: correlations with John Cunningham virus DNA and C-reactive protein level
}

\author{
This article was published in the following Dove Press journal: \\ Therapeutics and Clinical Risk Management \\ 9 October 2014 \\ Number of times this article has been viewed
}

\section{Roberta Lanzillo' \\ Raffaele Liuzzi² \\ Luca Vallefuoco ${ }^{3}$ \\ Marcello Moccial \\ Luca Amato' \\ Giovanni Vacca' \\ Veria Vacchiano' \\ Giuseppe Portella ${ }^{3}$ \\ Vincenzo Brescia Morra' \\ 'Neurological Sciences Department, Federico II University, ${ }^{2}$ Institute of Biostructure and Bioimaging, National Research Council, ${ }^{3}$ Clinical Pathology Department, Federico II University, Naples, Italy}

\begin{abstract}
Natalizumab-treated patients have a higher risk of developing progressive multifocal leukoencephalopathy. Exposure to John Cunningham virus (JCV) is a prerequisite for PML (progressive multifocal leukoencephalopathy). To assess JCV exposure in multiple sclerosis patients, we performed a serological examination, obtained the antibody index, performed realtime polymerase chain reaction (PCR) to detect JCV DNA in plasma and urine, and investigated the role of ultrasensitive C-reactive protein (usCRP) as a possible biological marker of JCV reactivation. We retrospectively analyzed consecutive natalizumab-treated multiple sclerosis patients who underwent a JCV antibody test through a two-step enzyme-linked immunosorbent assay (STRATIFY test) to the measure of serum usCRP levels, and to perform blood and urine JCV PCR. The studied cohort included 97 relapsing-remitting patients (60 women). Fifty-two patients $(53.6 \%)$ tested positive for anti-JCV antibodies. PCR showed JCV DNA in the urine of 30 out of 83 (36.1\%) patients and 28 out of 44 seropositive patients $(63.6 \%)$, with a $6.7 \%$ false-negative rate for the STRATIFY test. Normalized optical density values were higher in urinary JCV DNA-positive patients $(P<0.0001)$. Interestingly, the level of usCRP was higher in urinary JCV DNA-positive patients and correlated to the number of DNA copies in urine $(P=0.028)$. As expected, patients' age correlated with JCV seropositivity and with JC viruria ( $P=0.02$ and $P=0.001$, respectively). JC viruria was significantly correlated with a high JCV antibody index and high serum usCRP levels. We suggest that PCR and usCRP might be useful as markers of JCV reactivation, and that patients should be monitored between STRATIFY assessments.
\end{abstract}

Keywords: multiple sclerosis, John Cunningham virus, natalizumab, antibodies, polymerase chain reaction, ultrasensitive C-reactive protein

\section{Introduction}

Progressive multifocal leukoencephalopathy (PML) is a rare brain disease caused by the John Cunningham (JC) virus (JCV), a common polyomavirus. ${ }^{1}$ Primary infection by JCV usually occurs early in life, and the benign form of JCV remains asymptomatic in the kidneys throughout life. ${ }^{2,3}$ By means of complex interactions between the host and viral factors, JCV undergoes mutations in the regulatory region ${ }^{4}$ and in the coat protein of viral protein 1 (VP1). ${ }^{5}$ This causes a lytic infection of the brain's oligodendrocytes, which represents the pathogenetic event that drives PML development. ${ }^{5}$ The reasons why some patients develop PML and most others do not may be related to different factors, such as rare bone marrow or other sites of viral latency, the effects of 
drugs that immobilize specific progenitors into the periphery, host factors that predispose to viral replication, and trafficking of the virus into the brain where it may escape from a depleted or dysfunctional immune system. ${ }^{6}$ This serious rare disease generally occurs in severely immunocompromised individuals, especially in acquired immunodeficiency syndrome (AIDS) patients, as well as in some patients receiving immunosuppressive (mycophenolate mofetil) or biological (for example, efalizumab, natalizumab, alemtuzumab, and rituximab) therapies. ${ }^{7,8}$

Infection by JCV is a prerequisite for PML development and rates of seropositivity from 33\%-91\% have been previously reported..$^{7,9-20}$ This discrepancy in rates was due to differences in sample size, demographics and, most importantly, assay methodologies. ${ }^{7,9-20}$

Recently, natalizumab was introduced in multiple sclerosis (MS) therapy. Its presumed mode of action is the inhibition of T-cell/monocyte entry into the brain, and the white cell count, which most prominently circulates B-cells and especially pre-B-cells, is increased in natalizumab-treated patients. $^{21}$

Since PML cases developed while patients were on therapy with natalizumab, a two-step assay to detect anti-JCV antibodies in serum and plasma was established to provide a means to classify MS patients who have a detectable or nondetectable level of anti-JCV antibodies. ${ }^{22}$ The predictive value of this test was evident across $20 \mathrm{MS}$ natalizumabtreated patients whose sera were available before PML development, with a positive result (seropositivity) in all of the samples. ${ }^{23}$ However, a $2.5 \%$ false-negative rate and seroconversion during therapy with natalizumab have been reported. ${ }^{22,24}$ Although this rate is considered low, it should be taken into account. Eventually, Berger et $\mathrm{al}^{25}$ affirmed that JCV antibody detection is an excellent tool for stratifying patients for PML risk, but that it underestimates infection rates.

Another way to monitor viral exposure in natalizumabtreated patients is via real-time polymerase chain reaction (PCR) to detect JCV DNA copies in patients' fluids. ${ }^{26}$ Even if Rudick et $\mathrm{al}^{26}$ did not support JCV DNA testing in blood or urine samples with currently available PCR methodologies, because of its low sensitivity and low predictive value for PML, recently, Laroni et $\mathrm{al}^{27}$ re-evaluated urinary JCV DNA testing as a predictor of PML development and showed the presence of $5.5 \%$ false-negative JCV antibody tests in their population, reaffirming the role of PCR.

Since PCR is a time-intensive, expensive, and not an easily accessible technique, biological markers or predictors of JC reactivation would be highly necessary. Ultrasensitive C-reactive protein (usCRP) is considered a marker for unspecific inflammation, and it usually indicates a heightened state of inflammation in the body in response to many physical states, including fever, injury, and infection. ${ }^{28}$ Few studies report an increase of usCRP levels in AIDS patients on antiretroviral therapy, which is consistent with preexisting subclinical tuberculosis, before the development of unmasking tuberculosis-associated immune reconstitution inflammatory syndrome. ${ }^{29}$ Moreover, CRP has gained increasing interest as a possible predictive marker of opportunistic infections in AIDS patients, and as a supportive marker of immunosuppression. ${ }^{30}$ In light of this evidence, the aim of our study was to assess, in our natalizumab-treated MS patient cohort, the correlation of the JCV antibody index with the occurrence of JCV DNA in the patients' blood and urine (detected by PCR), and the role of usCRP as a possible biological marker of JCV reactivation.

\section{Materials and methods Patients}

We designed an observational retrospective study that was conducted on all consecutive relapsing-remitting MS patients treated with natalizumab, or during the first natalizumab administration at the MS Center of Federico II University of Naples from March-October 2011.

\section{Methods}

All of the clinical assessments and analyses were performed as part of routine clinical practice. Demographic and clinical data were collected. Concomitant diseases were recorded. The number of natalizumab administrations and previous therapy exposure were registered.

\section{Serological test}

A serological test for anti-JCV antibodies configured as a two-step assay consisting of an enzyme-linked immunosorbent assay was performed in a centralized laboratory in Denmark (by United Laboratories, Mandaluyong City, Philippines) (STRATIFY test). ${ }^{22}$ The result of this test was a dichotomous (negative/positive) result. Only successive normalized optical density $(\mathrm{nOD})\left(\mathrm{nOD}_{450}\right)$ values were used, and in the case of borderline results (nOD between 0.1 and 0.25 ), the percentage of inhibition during a confirmatory test was subsequently provided for scientific purposes. Patients who had negative results for the STRATIFY test, but positive results with PCR, were retested using a second-generation STRATIFY test. ${ }^{23}$ 


\section{Real-time PCR}

The presence of plasma or urinary JCV deoxyribonucleic acid (DNA) was used as a positive reference to determine false negative JCV antibodies patients.

The number of JCV DNA copies in plasma and urine samples was determined in 87 patients and 83 patients, respectively, using real-time PCR. For the isolation of viral DNA from $200 \mu \mathrm{L}$ of urine and $200 \mu \mathrm{L}$ of plasma samples, we used the Roche MagNA Pure LC Total Nucleic Acid Isolation Kit combined with the Roche MagNA Pure LC automated extractor (Hoffman-La Roche, Ltd, Basel, Switzerland). Blood samples were collected in sterile tubes with ethylenediaminetetraacetic acid $\mathrm{K} 3$ and centrifuged at $2,500 \mathrm{rpm} /$ minute for 15 minutes. The plasma was separated from the corpuscular part, and when necessary, was stored at $-20^{\circ} \mathrm{C}$ in sterile vials for molecular biology until analysis. Urine samples were stored under the same conditions as the plasma samples. The amount of JCV DNA was examined by real-time PCR using the LightCycler ${ }^{\circledR} 2.0$ (Hoffman-La Roche Ltd). The primers and probes were supplied by TIB MOLBIOL GmbH (Berlin, Germany). Briefly, a 174 bp fragment of the JCV genome was amplified with specific primers $^{31}$ and the amplification product was detected with fluorescence resonance energy transfer probes labeled with "LightCycler ${ }^{\mathbb{B}}$ Red 705". The amplified product was identified by a melting curve with a specific melting temperature of $68^{\circ} \mathrm{C}$ and was read at $705 \mathrm{~nm}$. A chain of DNA of $278 \mathrm{bp}$ was added to the mixture, and this represented an internal control, which was amplified in the presence of negative or low viral loads and revealed by probes labeled with LightCycler ${ }^{\circledR}$ Red 705. The specific melting temperature of this control was $50^{\circ} \mathrm{C}$, and amplification with its primers did not interfere with amplification of the target.

\section{Biochemistry}

Renal function laboratory tests (creatinine serum levels and proteinuria) and usCRP levels were performed at University Hospital "Federico II" DAsMeLab (Dipartimento Assistenziale di Medicina di Laboratorio).

\section{Statistical analysis}

Continuous normally distributed variables are shown as the mean \pm standard deviation. Continuous, but not normally distributed variables, are shown as the median and range. Categorical data are reported as percentages and 95\% confidence intervals (CIs). To compare continuous data, the unpaired Student's $t$-test or the nonparametric Mann-Whitney $U$-test was used when appropriate. The Kruskal-Wallis test was used to compare more than two groups. For categorical data, the $\chi^{2}$ test or Fisher's exact test were used when appropriate. To assess the level of concordance, the value of Cohen's $k$ was calculated. We adopted the levels reported by Landis and Knoch. ${ }^{32}$ Receiver operating characteristic (ROC) curve analysis was performed, and the Youden's index was used as possible threshold values for dividing patients into high-risk and low-risk groups regarding viral parameters. A $P$-value $<0.05$ was taken as statistically significant. Statistics was performed using MedCalc (MedCalc Software bvba, Ostend, Belgium).

\section{Results}

We included 97 relapsing-remitting MS patients (60 women) with a mean age of $38.2 \pm 11.2$ years, a mean disease duration of $7 \pm 4$ years, and a median number of natalizumab administrations of 17 (range: 0-41). No concomitant relevant diseases were present at the time of examination and renal function parameters were normal. The JCV antibody test was performed in all 97 patients, while PCR analysis of JCV DNA in urine samples was performed in 83 patients. Furthermore, the presence of JCV DNA in the blood was assessed in 89 patients of our cohort. Twenty-two patients $(22.6 \%)$ were on natalizumab as the first therapy (naïve patients), 75 patients $(77.3 \%)$ were on natalizumab as second-line therapy, and eleven patients $(11.3 \%)$ had already used immunosuppressive drugs. The mean duration of previous therapies, including any treatment for MS, was $51 \pm 46$ months.

In our cohort, the anti-JCV antibody prevalence was $53.6 \%$ (52 patients), with a median nOD value of 0.62 (range: $0.10-1.73)$. A confirmatory test was performed in 23 "borderline" patients, as defined in the "Materials and methods" section, and 13 patients were considered negative (inhibition test below $40 \%$ ) while ten were positive for the presence of anti-JCV antibodies.

Real-time PCR showed the presence of urinary JCV DNA in 30 out of 83 (36.1\%) examined patients (Figure 1) and plasma JCV DNA in one patient out of 89 (1.1\%). Among the 44 seropositive patients tested for the presence of urinary JCV DNA, 28 (63.6\%) showed positive results (Table 1). Two seronegative patients showed urinary JCV DNA copies $(6.7 \%$ false-negative rate). The first patient was a 48 -year-old man at his sixth infusion of natalizumab, with a nOD value of 0.101 and $35 \%$ inhibition, and he had presented with 300,000 JCV DNA copies $/ \mathrm{mL}$ in his urine. Six months later, he was retested still using the first-generation STRATIFY test, and he again presented with a low antibody titer (nOD $=0.107$; inhibition: $34.8 \%$ ), which was considered negative during a confirmatory test ( $\mathrm{nOD}=0.093)$. Eventually, 1 year later, 


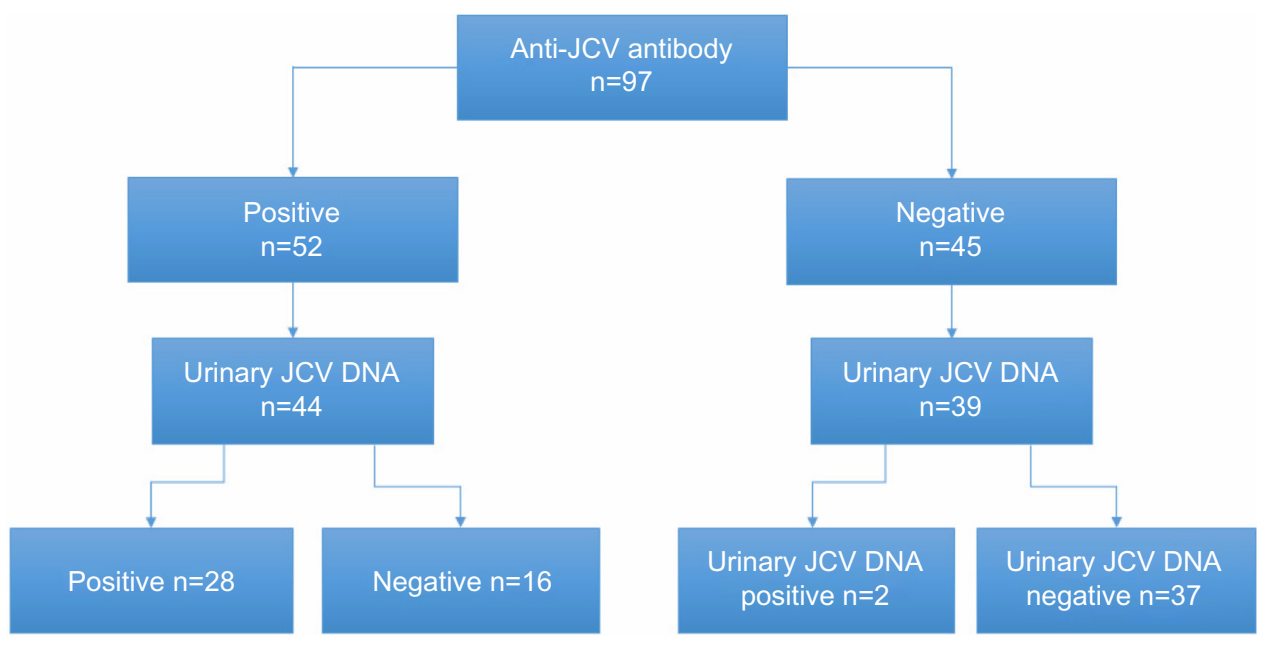

Figure I Distribution of anti-JCV antibody and distribution of urinary JCV DNA in our cohort. Abbreviations: JCV, John Cunningham virus; n, number; DNA, deoxyribonucleic acid.

he was tested with the second-generation STRATIFY test and the result was an indeterminate titer and a confirmatory test, which resulted in a negative result (index value not available). Furthermore, he showed fluctuating urinary JCV DNA levels over 2 years. The second patient was a 52-year-old woman at her 26th natalizumab infusion, with a nOD value of 0.093 and a constant presence of viral DNA for 28 months. The same patient was retested 1 year later using a first-generation STRATIFY assay and was considered positive with a nOD of 0.58 . Therefore, excluding this patient that resulted seropositive at repetitive tests, the false-negative rate decreased to $3.3 \%$. A unique patient (a 44-year-old woman) was positive for plasma JCV DNA and was seropositive, with a high
nOD (=1.731) and 2,650,000 copies/mL of JCV DNA in her urine, at her 30th natalizumab administration. At repetitive tests, she was negative for JCV DNA in her plasma, and the copies of DNA in her urine were slightly decreased. She was discontinued from natalizumab, without any relevant complications.

In the entire cohort, the concordance rate between the presence of JCV antibodies and urinary JCV DNA was moderate $(k=0.57)$. The sensitivity and specificity of the JCV antibody test were $93.3 \%$ (95\% CI: $77.9 \%-99.2 \%)$ and $69.8 \%$ (95\% CI: 55.7\%-81.7\%), respectively.

The nOD values were higher in urinary JCV DNApositive patients than in negative ones $(P<0.0001$, Figure 2$)$,

Table I Clinical characteristics of the multiple sclerosis patients classified according the results of the presence of anti-JCV antibodies

\begin{tabular}{|c|c|c|c|c|}
\hline & \multicolumn{4}{|l|}{ Patients } \\
\hline & $\begin{array}{l}\text { Anti-JCV antibodies, } \\
\text { negative }(n=45)\end{array}$ & $\begin{array}{l}\text { Anti-JCV antibodies, } \\
\text { positive }(n=52)\end{array}$ & $P$ & Statistical test \\
\hline Age (years) & $35.37 \pm 11.48$ & $40.59 \pm 10.50$ & 0.021 & Student's $t$-test \\
\hline \multicolumn{5}{|l|}{ Sex } \\
\hline Male & 18 & 19 & 0.57 & $\chi^{2}$ \\
\hline Female & 34 & 26 & & \\
\hline Natalizumab administrations (n) & $12(0-4 \mid)$ & $19(0-40)$ & 0.32 & Mann-Whitney U-test \\
\hline Previous therapies (months) & $48(0-148)$ & $45(0-146)$ & 0.89 & Mann-Whitney U-test \\
\hline usCRP (mg/L) & $0.80(0.10-10.70)$ & $0.95(0.15-18.30)$ & $0.4 \mathrm{I}$ & Mann-Whitney U-test \\
\hline \multicolumn{5}{|l|}{ Previous immunosuppressive drugs } \\
\hline No & 40 & 46 & 0.95 & $\chi^{2}$ \\
\hline Yes & 5 & 6 & & \\
\hline JCV antibody test (nOD) & $0.08(0.06-0.16)$ & $0.62(0.10-1.73)$ & $<0.0001$ & Mann-Whitney U-test \\
\hline \multicolumn{5}{|c|}{ Urinary JCV DNA (available only in 83 patients) } \\
\hline Positive $(n=30)$ & 2 & 28 & $<0.0001$ & Fisher's exact test \\
\hline Negative $(n=53)$ & 37 & 16 & & \\
\hline
\end{tabular}

Abbreviations: JCV, John Cunningham virus; n, number; usCRP, ultrasensitive C-reactive protein; nOD, normalized optical density; DNA, deoxyribonucleic acid. 
but this was unrelated to the number of DNA copies. From the ROC analyses of urinary JCV DNA, the nOD threshold value to classify positive or negative patients was 0.197 (Figure 3).

Seropositivity was not related to any clinical parameters, the number of natalizumab administrations, or previous immunosuppressive therapies, but it was related to age $(P=0.021)$. The presence of urinary JCV DNA was also only related to age $(P=0.001$; Table 2$)$ and, interestingly, to serum usCRP levels $(P=0.028$; Figure 4$)$. Serum usCRP levels were also correlated with the number of DNA copies in urine $(P=0.027)$ and with age $(P<0.001)$, but they were not correlated with any other demographic or clinical parameter (sex, disease duration, previous therapies, previous relapses, EDSS, and the number of natalizumab administrations). When patients were stratified for concomitant urinary JCV DNA and seropositivity or seronegativity $(28+/+, 2+/-, 16-/+, 37-/-)$, usCRP was not different among the groups $(P=0.063)$. Renal function parameters and urinalysis results were not related to the presence of JCV DNA in urine samples.

\section{Discussion}

Risk stratification of PML in natalizumab-treated patients is a hot topic in the MS field. Use of the STRATIFY test to measure JCV exposure, despite its sensitivity, is still limited by the fact that no validated test exists to confirm true JCV

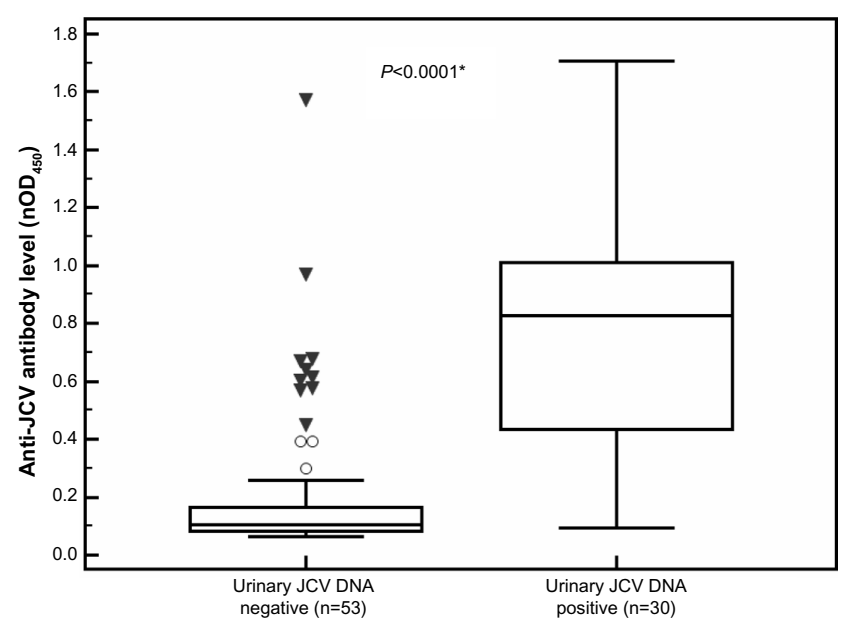

Figure 2 Anti-JCV antibody levels in MS patients who were JCV DNA-positive or -negative, as determined in urine samples.

Notes: The distribution of enzyme-linked immunosorbent assay results in nOD values are depicted as box plots for JCV DNA-negative $(n=53)$ and -positive $(n=30)$ results in urine samples. The boxes represent the IQR, with the median line in the center; brackets represent observation in I.5× IQR; circles are observation beyond the I.5 $\times$ IQR (outliers), triangles are observation beyond the $3 \times \mathrm{IQR}$ (far-outliers). A significant difference was observed between the two groups. *Mann-Whitney U-test.

Abbreviations: JCV, John Cunningham virus; nOD, normalized optical density; DNA, deoxyribonucleic acid; $n$, number; MS, multiple sclerosis; IQR, interquartile range.

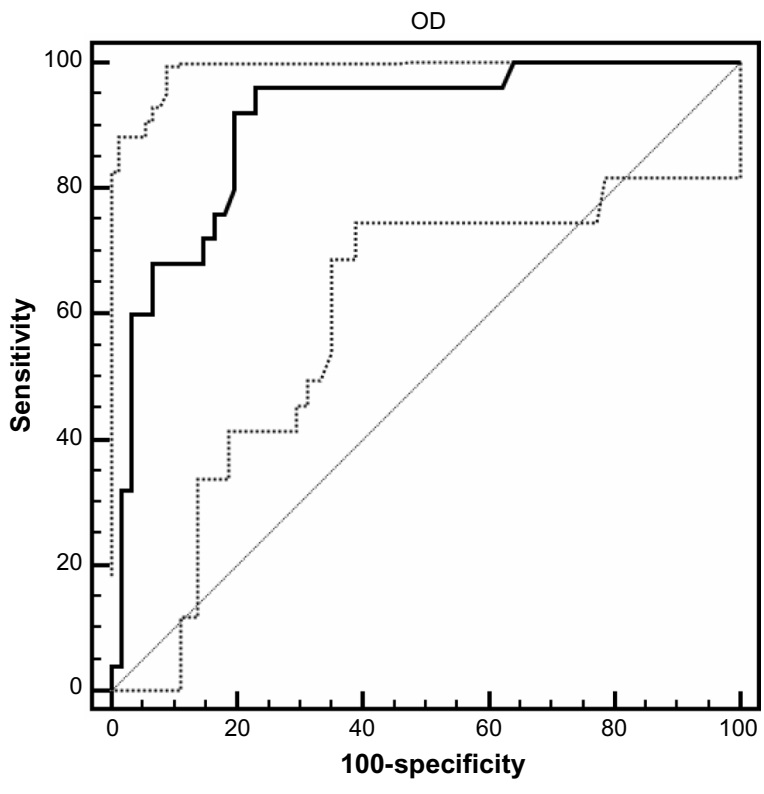

Figure 3 ROC curve of the normalized anti-JCV level $\left(\mathrm{nOD}_{450}\right)$ values for the diagnosis of urinary JCV DNA.

Notes: The area under the ROC curve was 0.903 . The dotted lines represent the $95 \%$ confidence interval.

Abbreviations: OD, optical density; ROC, receiver operating characteristic; JCV, John Cunningham virus; nOD, normalized optical density; DNA, deoxyribonucleic acid.

exposure. A second-generation test with higher sensitivity was recently developed. ${ }^{23}$ Only recently, the antibody index for JCV has become available, showing some misinterpretation of results in the past, especially in the low titer range, leading to the perception that with binary positive/negative results there were some misinterpretations especially in the low titre range. ${ }^{33}$ In this study, we measured the prevalence of JCV seropositivity with a first-generation STRATIFY test, with the related nOD values, and we correlated them to the presence of JCV DNA in blood and urine and to usCRP levels.

We found that the prevalence of JCV seropositivity was $53.6 \%$, which is comparable with findings from larger studies ${ }^{34}$ and with data obtained from Italian patients..$^{27,35}$ This prevalence was related to age, but not to sex, previous exposure to therapies, or the number of natalizumab administrations. The presence of JCV DNA in urine samples, which is considered as a sign of active proliferation of the virus, was found in $63.6 \%$ of our JCV seropositive patients and in $36.1 \%$ of the whole population, similar to previous data. ${ }^{27}$ We confirmed that shedding of the virus in biological fluids was not secondary to natalizumab treatment, because it was not related to the number of administrations, but it was related to age. Interestingly, the presence of JCV DNA in the urine was related to serum usCRP levels and to higher JCV antibody nOD values. 
Table 2 Clinical characteristics of the multiple sclerosis patients classified according the results of urinary JCV DNA presence

\begin{tabular}{|c|c|c|c|c|}
\hline & \multicolumn{4}{|l|}{ Patients } \\
\hline & $\begin{array}{l}\text { Urinary JCV DNA, } \\
\text { negative }(n=53)\end{array}$ & $\begin{array}{l}\text { Urinary JCV DNA, } \\
\text { positive }(n=30)\end{array}$ & $P$ & Statistical test \\
\hline Age (years) & $35.47 \pm 10.91$ & $43.67 \pm 8.7$ & 0.001 & Student's $t$-test \\
\hline \multicolumn{5}{|l|}{ Sex } \\
\hline Male & 21 & II & 0.97 & $\chi^{2}$ \\
\hline Female & 32 & 19 & & \\
\hline Natalizumab administrations ( $\mathrm{n}$ ) & $17(0-4 \mid)$ & $2 I(I-38)$ & 0.242 & Mann-Whitney U-test \\
\hline Previous therapies (months) & $31(0-148)$ & $49(0-146)$ & 0.339 & Mann-Whitney U-test \\
\hline usCRP $(\mathrm{mg} / \mathrm{L})$ & $0.75(0.10-10.20)$ & $1.35(0.15-18.3)$ & 0.028 & Mann-Whitney U-test \\
\hline \multicolumn{5}{|l|}{ Previous immunosuppressive drugs } \\
\hline No & 49 & 26 & 0.638 & Fisher's exact test \\
\hline Yes & 4 & 4 & & \\
\hline JCV antibody test (nOD) & $0.10(0.06-0.97)$ & $0.76(0.09-1.73)$ & $<0.0001$ & Mann-Whitney U-test \\
\hline
\end{tabular}

Abbreviations: JCV, John Cunningham virus; DNA, deoxyribonucleic acid; n, number; usCRP, ultrasensitive C-reactive protein; nOD, normalized optical density.

JCV DNA presence in the blood has never been clearly related to PML development, while there are some favorable reports of JCV DNA presence in urine as a risk factor for developing PML, as already cited (Rudick et $\mathrm{al}^{26}$ and Laroni et $\mathrm{al}^{27}$ ). To the best of our knowledge, there are no correlations of JCV DNA in the blood or urine with cerebrospinal fluid viral presence (not constant in PML patients) and to PML disease activity.

An increase in JCV viruria with age, consequent to a reactivation of the retained latent kidney's viruses is a well-known phenomenon, ${ }^{16,36}$ while its association with usCRP levels is a completely new finding that might open a

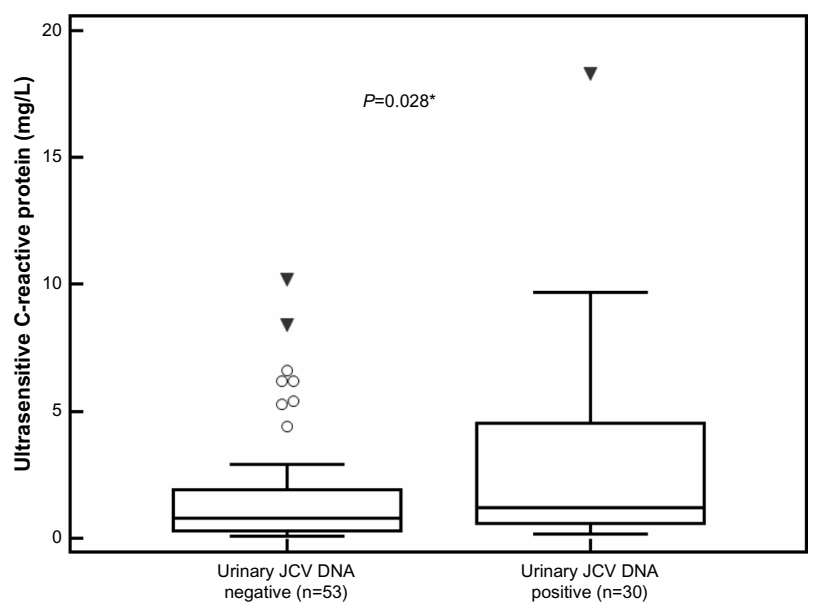

Figure 4 Ultrasensitive C-reactive protein levels in MS patients who were positive or negative for urinary JCV DNA.

Notes: The distribution of the enzyme-linked immunosorbent assay results of the $n O D$ values are depicted as box plots for negative $(n=53)$ and positive $(n=30)$ urinary JCV DNA. The box represents the IQR, with the median line in the center; the brackets represent observation in I.5 $\times$ IQR; circle are observation beyond the I.5× IQR (outliers), triangles are observations beyond the $3 \times I Q R$ (far-outliers). A significant difference was observed between the two groups. *Mann-Whitney U-test.

Abbreviations: JCV, John Cunningham virus; DNA, deoxyribonucleic acid; n, number; MS, multiple sclerosis; nOD, normalized optical density; IQR, interquartile range. novel prospective in the field. Nevertheless, we must consider that usCRP is an unspecific test, which might be increased as a consequence of an inflammatory state; however, in our patients, no concomitant diseases related to an inflammatory state were recorded. Therefore, its role as a marker of urinary shedding of the JC virus, secondary to its reactivation, is a very appealing hypothesis.

Moreover, we found a false-negative rate of 6.7, which is higher than the rate originally described. ${ }^{22}$ When we examined the two seronegative patients with JCV viruria in detail, we found that the first patient (a man with persistent negative values) was a false-negative patient with a constantly low immune response to JCV and a low viral load, while the second patient had fluctuating antibody levels over time, leading to a false-negative result at the first test. Therefore, the false-negative rate decreased to $3.3 \%$ with repetitive tests, as described in the literature. ${ }^{22}$

However, calculation of a false-negative rate, and the sensitivity and specificity of the anti-JCV antibody test used in this study, was greatly limited by the size of the cohort. Moreover, when using JC viruria to validate exposure data, repetitive sampling in the same individuals would add important information because excretion in urine occurs intermittently.

\section{Conclusion}

In conclusion, in our study, the two methodologies used to determine JCV exposure in natalizumab-treated patients showed a comparable prevalence of viral contact and active replication with that described in the literature in other populations. ${ }^{27,34,35}$ However, such methodologies shared a modest concordance $(k=0.57)$, with $63.6 \%$ of seropositive patients showing an active viral replication. This is an 
expected discrepancy in a transversal study design, due to the intermittent excretion in urine of JCV DNA. Therefore, because of the relevant usefulness of the anti-JCV antibody assays as a tool for stratifying MS patients into higher or lower risk for PML development, PCR might be an additional useful approach to test viral reactivation and load. Additionally, during natalizumab therapy, in the interval between performing two STRATIFY tests, PCR can provide evidence for a patient's first exposure to JCV. Together with usCRP levels, PCR might represent a useful tool to follow up with JCV seropositive patients, to increase their surveillance, and to determine whether active viral replication is ongoing. Eventually, the recent availability of the JCV antibody index through a second-generation STRATIFY test will help when making therapeutic decisions, avoiding false-negative results. Although these are appealing possibilities, they need confirmation through larger and longitudinal studies.

\section{Acknowledgments}

We are grateful to Biogen Idec for providing the JCV antibody test facilities and Unilabs for kindly providing nOD values.

\section{Disclosure}

Roberta Lanzillo has received honoraria from Bayer Shering, Biogen Idec, Merck-Serono, TEVA, and Novartis for giving lectures or being on scientific boards. Giovanni Vacca has received honoraria from Bayer Shering for consultancy. Vincenzo Brescia Morra has received honoraria from Bayer Shering, Biogen Idec, Merck-Serono, TEVA, Aventis, and Novartis for giving lectures or being on scientific boards. Raffaele Liuzzi, Luca Vallefuoco, Luca Amato, Veria Vacchiano, Marcello Moccia, and Giuseppe Portella report no conflicts of interest in this work.

\section{References}

1. Agostini HT, Ryschkewitsch CF, Singer EJ, Stoner GL. Co-infection with two JC virus genotypes in brain, cerebrospinal fluid or urinary tract detected by direct cycle sequencing of PCR products. $J$ Neurovirol. 1996;2(4):259-267.

2. Chesters PM, Heritage J, McCance DJ. Persistence of DNA sequences of $\mathrm{BK}$ virus and JC virus in normal human tissues and in diseased tissues. J Infect Dis. 1983;147(4):676-684.

3. Heritage J, Chesters PM, McCance DJ. The persistence of papovavirus BK DNA sequences in normal human renal tissue. J Med Virol. 1981;8(2):143-150.

4. Pietropaolo V, Videtta M, Fioriti D, et al. Rearrangement patterns of JC virus noncoding control region from different biological samples. J Neurovirol. 2003;9(6):603-611.

5. Sunyaev SR, Lugovskoy A, Simon K, Gorelik L. Adaptive mutations in the JC virus protein capsid are associated with progressive multifocal leukoencephalopathy (PML). PLoS Genet. 2009;5(2):e1000368.
6. Major EO. Progressive multifocal leukoencephalopathy in patients on immunomodulatory therapies. Annu Rev Med. 2010;61:35-47.

7. Martin SI, Marty FM, Fiumara K, Treon SP, Gribben JG, Baden LR. Infectious complications associated with alemtuzumab use for lymphoproliferative disorders. Clin Infect Dis. 2006;43(1):16-24.

8. Neff RT, Hurst FP, Falta EM, et al. Progressive multifocal leukoencephalopathy and use of mycophenolate mofetil after kidney transplantation. Transplantation. 2008:86(10):1474-1478.

9. Antonsson A, Green AC, Mallitt KA, et al. Prevalence and stability of antibodies to the BK and JC polyomaviruses: a long-term longitudinal study of Australians. J Gen Virol. 2010;91(Pt 7):1849-1853.

10. Carter JJ, Madeleine MM, Wipf GC, et al. Lack of serologic evidence for prevalent simian virus 40 infection in humans. $J$ Natl Cancer Inst. 2003;95(20):1522-1530.

11. Egli A, Infanti L, Dumoulin A, et al. Prevalence of polyomavirus BK and JC infection and replication in 400 healthy blood donors. J Infect Dis. 2009;199(6):837-846.

12. Engels EA, Rollison DE, Hartge P, et al. Antibodies to JC and BK viruses among persons with non-Hodgkin lymphoma. Int $J$ Cancer. 2005;117(6):1013-1019.

13. Grabowski MK, Viscidi RP, Margolick JB, Jacobson LP, Shah KV. Investigation of pre-diagnostic virological markers for progressive multifocal leukoencephalopathy in human immunodeficiency virusinfected patients. J Med Virol. 2009;81(7):1140-1150.

14. Kean JM, Rao S, Wang M, Garcea RL. Seroepidemiology of human polyomaviruses. PLoS Pathog. 2009;5(3):e1000363.

15. Knowles WA, Pipkin P, Andrews N, et al. Population-based study of antibody to the human polyomaviruses BKV and JCV and the simian polyomavirus SV40. J Med Virol. 2003;71(1):115-123.

16. Matos A, Duque V, Beato S, da Silva JP, Major E, Meliço-Silvestre A. Characterization of JC human polyomavirus infection in a Portuguese population. J Med Virol. 2010;82(3):494-504.

17. Padgett BL, Walker DL. Prevalence of antibodies in human sera against JC virus, an isolate from a case of progressive multifocal leukoencephalopathy. J Infect Dis. 1973;127(4):467-470.

18. Rollison DE, Engels EA, Halsey NA, Shah KV, Viscidi RP, Helzlsouer KJ. Prediagnostic circulating antibodies to JC and BK human polyomaviruses and risk of non-Hodgkin lymphoma. Cancer Epidemiol Biomarkers Prev. 2006;15(3):543-550.

19. Stolt A, Sasnauskas K, Koskela P, Lehtinen M, Dillner J. Seroepidemiology of the human polyomaviruses. J Gen Virol. 2003;84(Pt 6): 1499-1504.

20. Verbeeck J, Van Assche G, Ryding J, et al. JC viral loads in patients with Crohn's disease treated with immunosuppression: can we screen for elevated risk of progressive multifocal leukoencephalopathy? Gut. 2008;57(10):1393-1397.

21. Krumbholz M, Meinl I, Kümpfel T, Hohlfeld R, Meinl E. Natalizumab disproportionately increases circulating pre-B and $\mathrm{B}$ cells in multiple sclerosis. Neurology. 2008;71(17):1350-1354.

22. Gorelik L, Lerner M, Bixler S, et al. Anti-JC virus antibodies: implications for PML risk stratification. Ann Neurol. 2010;68(3):295-303.

23. Lee P, Plavina T, Castro A, et al. A second-generation ELISA (STRATIFY JCV ${ }^{\mathrm{TM}}$ DxSelect ${ }^{\mathrm{TM}}$ ) for detection of JC virus antibodies in human serum and plasma to support progressive multifocal leukoencephalopathy risk stratification. J Clin Virol. 2013;57(2):141-146.

24. Trampe AK, Hemmelmann C, Stroet A, et al. Anti-JC virus antibodies in a large German natalizumab-treated multiple sclerosis cohort. Neurology. 2012;78(22):1736-1742.

25. Berger JR, Houff SA, Gurwell J, Vega N, Miller CS, Danaher RJ. JC virus antibody status underestimates infection rates. Ann Neurol. 2013;74(1):84-90.

26. Rudick RA, O'Connor PW, Polman CH, et al. Assessment of JC virus DNA in blood and urine from natalizumab-treated patients. Ann Neurol. 2010;68(3):304-310.

27. Laroni A, Giacomazzi CG, Grimaldi L, et al. Urinary JCV-DNA testing during natalizumab treatment may increase accuracy of PML risk stratification. J Neuroimmune Pharmacol. 2012;7(3):665-672. 
28. Ablij H, Meinders A. C-reactive protein: history and revival. Eur $J$ Intern Med. 2002;13(7):412.

29. Haddow LJ, Dibben O, Moosa MY, Borrow P, Easterbrook PJ. Circulating inflammatory biomarkers can predict and characterize tuberculosisassociated immune reconstitution inflammatory syndrome. AIDS. 2011;25(9):1163-1174.

30. Nixon DE, Landay AL. Biomarkers of immune dysfunction in HIV. Curr Opin HIV AIDS. 2010;5(6):498-503.

31. Narayanan M, Szymanski J, Slavcheva E, et al. BK virus associated renal cell carcinoma: case presentation with optimized PCR and other diagnostic tests. Am J Transplant. 2007;7(6):1666-1671.

32. Landis JR, Koch GG. The measurement of observer agreement for categorical data. Biometrics. 1977;33(1):159-174.
33. Lanzillo R, Liuzzi R, Amato L, et al. JCV antibodies index on natalizumab treatment: fluctuations and seroconversion. Multiple Sclerosis Journal. 2013;19(Suppl 11):P599.

34. Bozic C, Richman S, Plavina T, et al. Anti-John Cunnigham virus antibody prevalence in multiple sclerosis patients: baseline results of STRATIFY-1. Ann Neurol. 2011;70(5):742-750.

35. Olsson T, Achiron A, Alfredsson L, et al. Anti-JC virus antibody prevalence in a multinational multiple sclerosis cohort. Mult Scler. 2013;19(11):1533-1538.

36. Kitamura T, Aso Y, Kuniyoshi N, Hara K, Yogo Y. High incidence of urinary $\mathrm{JC}$ virus excretion in nonimmunosuppressed older patients. J Infect Dis. 1990;161(6):1128-1133.

\section{Publish your work in this journal}

Therapeutics and Clinical Risk Management is an international, peerreviewed journal of clinical therapeutics and risk management, focusing on concise rapid reporting of clinical studies in all therapeutic areas, outcomes, safety, and programs for the effective, safe, and sustained use of medicines. This journal is indexed on PubMed Central, CAS,
EMBase, Scopus and the Elsevier Bibliographic databases. The manuscript management system is completely online and includes a very quick and fair peer-review system, which is all easy to use. Visit http://www.dovepress.com/testimonials.php to read real quotes from published authors.

Submit your manuscript here: http://www.dovepress.com/therapeutics-and-clinical-risk-management-journal 